\title{
RESISTANCE TRAINING IMPROVES THE BLOOD \\ PRESSURE AND FUNCTIONAL PERFORMANCE \\ OF INDIVIDUALS WITH T2DM
}

Original Article

ARTIGO ORIGINAL

TREINAMENTO RESISTIDO MELHORA A PRESSÃO ARTERIAL EO DESEMPENHO FUNCIONAL Artículo Original

DEPESSOAS COMDM2

\author{
ENTRENAMIENTO RESISTIDO MEJORA LA PRESIÓN ARTERIAL Y EL DESEMPEÑO FUNCIONAL \\ DELASPERSONAS CONDM2
}

\begin{abstract}
Jefferson Thiago Gonela' (iD (Physical Education Professional)

Vanilde de Castro $^{2}$ (iD)

(Mathematician)

Maria Lúcia Zanetti (iD)

(Nurse)

1. Centro Universitário Moura Lacerda de Ribeirão Preto, Faculdade de Educação Física, Ribeirão Preto, São Paulo, Brazil. 2. Escola de Enfermagem de Ribeirão Preto, Department of General and Specialized Nursing, Ribeirão Preto, São Paulo, Brazil.
\end{abstract}

\section{Correspondence:}

Jefferson Thiago Gonela Centro Universitário Moura Lacerda de Ribeirão Preto, Faculdade de Educação Física. Av. Dr. Oscar de Moura Lacerda, 1520, Independência. 14076510. Ribeirão Preto, SP, Brazil. jeffersoneduca@yahoo.com.br

\begin{abstract}
Introduction: Studies presenting the benefits in people with type 2 Diabetes Mellitus (T2DM) undergoing resistance training with one exercise for each muscle group, with three sets at the same intensity. Objective: To compare functional capacity and blood pressure before and after weight training. Methods: Twenty-three patients participated in a weight training program. Maximum strength and functional assessment tests were performed for the lower and upper limbs. The intervention time was 16 weeks, 12 of which consisted of training and four of evaluations. There was an increase in volume with the number of exercises and an increase in intensity with incremental weights. Results: There was significant improvement in most of the functional tests. In the $5 x$ sit-to-stand test in the pre-training period, nine patients recorded times greater than 13.6 seconds. In the post-training period, four maintained the above time, but two reduced the time from 16.1 and 19.6 to 13.9 seconds. In the maximum load strength test there are a significant increase in both upper and lower limbs with $20.8 \%$ and $23.4 \%$, respectively. After the training period, there was a significant reduction in systolic blood pressure both at rest and after exercise. Conclusion: The weight training program improved muscle strength, functional capacity and blood pressure in patients with type 2 diabetes mellitus. Level of evidence IV; Therapeutic study - Investigation of treatment outcomes.
\end{abstract}

Keywords: Diabetes mellitus, type 2; Exercise; Resistance training; Postural balance; Arterial pressure; Hypertension.

\section{RESUMO}

Introdução: Estudos apresentando os benefícios em pessoas com Diabetes Mellitus tipo 2 (DM2) submetidas ao treinamento resistido com um exercício para cada grupo muscular com três séries na mesma intensidade. Objetivos: Comparar a capacidade funcional e a pressão arterial antes e após o treinamento com pesos. Métodos: Vinte e três pacientes participaram de um programa de treinamento com pesos. Foram realizados testes de força máxima para os membros inferiores e superiores e de avaliação funcional. O tempo de intervenção foi de 16 semanas, sendo 12 de treinamento e quatro de avaliações. Houve aumento do volume, com o número de exercícios, e da intensidade, como incremento de pesos. Resultados: Houve melhora significativa na maioria dos testes funcionais. No teste de levantar-se da cadeira cinco vezes, no pré-treinamento, nove pacientes apresentaram tempo superior a 13,6 segundos. No pós-treinamento, quatro mantiveram o tempo acima, mas dois reduziram o tempo de 16, 1 e 19,6 para 13,9 segundos. No teste de força de carga máxima, verificou-se aumento significativo tanto nos membros superiores quanto inferiores com 20,8\% e 23,4\%, respectivamente. Após o treinamento, verificou-se redução significativa da pressão arterial sistólica tanto em repouso quanto após o esforço. Conclusões: O programa de treinamento com pesos melhorou a força muscular, a capacidade funcional e a pressão arterial dos pacientes com diabetes mellitus tipo 2. Nível de evidência IV; Estudo terapêutico - Investigação dos resultados do tratamento.

Descritores: Diabetes mellitus tipo 2; Exercício; Treinamento de resistência; Equilíbrio postural; Pressão arterial; Hipertensão.

\section{RESUMEN}

Introducción: Evaluación de los beneficios del entrenamiento resistido en personas con Diabetes Mellitus tipo 2 (DM2) que realizaron un ejercicio para cada grupo muscular, con tres series en la misma intensidad. Objetivos: Comparar la capacidad funcional y la presión arterial antes y después del entrenamiento con pesos. Métodos: Veintitrés pacientes participaron en un programa de entrenamiento con pesos. Fueron realizados tests de fuerza máxima para los miembros inferiores y superiores y evaluación funcional. El tiempo de intervención fue de 16 semanas, 12 de entrenamiento y cuatro de evaluaciones. Hubo un aumento del volumen, con el número de ejercicios, y de la intensidad, con el aumento en pesos. Resultados: Hubo mejora significativa en la mayoría de los tests funcionales. En el test de levantarse de la silla cinco veces, en el pre-entrenamiento, nueve pacientes presentaron tiempo superior a 13,6 segundos. En el post-entrenamiento, cuatro mantuvieron el tiempo anterior, pero dos redujeron el tiempo de 16,1 y 19,6 a 13,9 segundos. 
En el test de fuerza de carga máxima, se verificó aumento significativo tanto en los miembros superiores como en los inferiores con 20,8\% y 23,4\%, respectivamente. Después del entrenamiento, se verificó reducción significativa de la presión arterial sistólica tanto en reposo como después del esfuerzo. Conclusiones: El programa de entrenamiento con pesos mejoró la fuerza muscular, la capacidad funcional y la presión arterial de los pacientes con Diabetes Mellitus tipo 2. Nivel de evidencia IV; Estudio terapéutico - Investigación de los resultados del tratamiento.

Descriptores:Diabetes mellitus tipo 2; Ejercicio; Entrenamiento deresistencia; Balancepostural; Presión arterial; Hipertensión.

\section{INTRODUCTION}

It is an acknowledged fact that physical activity for 30 minutes a day, five days a week, at moderate to intense intensity, reduces the risk of cardiovascular diseases and contributes to the reduction of body weight and blood pressure. ${ }^{1-2}$

Despite the benefits of physical activity for individuals with type 2 Diabetes Mellitus (T2DM), a previous study showed that $12.1 \%$ individuals with T2DM are sedentary, i.e., do not engage in ten minutes of physical activity in household, yard or garden chores, work, transport and leisure activities. Furthermore, 56.8\% do not engage in leisure-time physical activity, and $20.5 \%$ obtain health benefits. ${ }^{3}$ Only $12 \%$ of older adults undertake some type of muscle strength training. ${ }^{1}$

Overweight and obese people with T2DM are mostly sedentary, and have lacked motivation and found it difficult to undertake aerobic power training exercises for several years. Strength training can become appealing and may favor a change in behavior with respect to the variables involved. ${ }^{4}$ However, although this type of training increases muscle strength and reduces body fat, effective results in glycemic and lipid control are not always evident.,5 On the other hand, aerobic and resistance training contribute to a reduction in blood pressure (BP) ${ }^{7}$ levels. However, there are few studies on resistance training and functional capacity of patients with T2DM.,9

On the other hand, the benefits for patients undergoing a resistance exercise program were evidenced with one type of exercise for each muscle group, with three sets for each exercise and the same intensity. $4,5,10,11$ In view of the above, the question is: is hypertrophic resistance training with an increase in the number of exercises and sets for muscle groups and increased intensity capable of producing additional benefits for elderly people with T2DM?

The aim of this study was to evaluate the functional capacity of elderly patients with T2DM before and after a hypertrophic resistance training program with increased training volume and intensity.

\section{MATERIALS AND METHODS}

A prospective comparative study conducted at the District Basic Health Unit (UBDS). The population consisted of 355 patients with T2DM from the Endocrinology Outpatient Clinic. Patients with T2DM, aged 60 and over, of both sexes, with a contact telephone number and cardiac stress test report, were included in the study. Patients with type 1 diabetes mellitus (T1DM), heart disease, acute myocardial infarction and stroke, or uncontrolled BP entered in their medical record were excluded, as were those with difficulty understanding the guidelines of the scheduled activities and those who had failed the cardiac stress test. Of the 355 patients, 107 were considered potentially eligible. We excluded 79 patients with T2DM who did not meet the inclusion criteria. The sample consisted of 28 patients with T2DM.

To assess balance and the risk of falls, we used tandem stance, ${ }^{12}$ the timed unipedal stance test ${ }^{13}$ and the $5 x$ sit-to-stand test. ${ }^{14}$ To assess gait acceleration capacity we used the 10 meter walk test. ${ }^{14}$ We also used the Battery of Activities of Daily Living for Elderly Physically Independent Test, validated by Andreotti and Okuma. ${ }^{15}$

The maximum repetition test was used to estimate upper and lower limb strength. When the participant performed between one and ten repetitions with concentric failure or technical error, the test was interrupted. Weight and number of repetitions were recorded. ${ }^{16}$ The calculation used to estimate maximum load was: 1-RM = 100 * rep load / $\left(102.78-2.78 *\right.$ rep). ${ }^{17}$

Data collection and training took place at a private academy located near UBDS after approval by the Institutional Review Board and signing of the informed consent form (ICF). The electrocardiogram was performed at a specialized clinic. The intervention time was 16 weeks, with 12 weeks of training and four of evaluations.

For the $800 \mathrm{~m}$ walk a flat track was built in a town square. Before the start of the strength tests, the participants underwent three adaptation sessions without weights to standardize the evaluations. Training intensity was $60 \%$ at the beginning and reached $80 \%$ at the end of the period. It was recommended that participants perform movements up to almost the point of concentric failure, according to the type of contraction endorsed in hypertrophic strength resistance training. Five participants withdrew over the course of the study, which lasted for 16 weeks.

Capillary blood samples were collected at the beginning of each training session. The protocol was as follows: 1- glycemia lower than 100 mg/dL, offer sweetened juice; 2- glycemia greater than 300 mg/dL, perform three sets of one exercise and check capillary blood glucose; $2 \mathrm{a}$ - glycemia lower than the initial reading, continue training; $2 \mathrm{~b}$ - if higher than the initial reading, indicate the end of the training session and refer for a medical appointment at UBDS.

With regard to Blood Pressure (BP), we adhered to the following protocol: Systolic blood pressure (SBP) $\geq 180 \mathrm{mmHg}$ and Diastolic blood pressure (DBP) $\geq 100 \mathrm{mmHg}$, perform three sets of one exercise and check BP. A- If there was a decline in BP levels, the training was continued; B- stable, another check was performed; C- if BP was elevated, the training was interrupted.

Before starting the specific exercises, the participants performed stretches for 10 minutes. One set was performed without load for localized warm-up on the first apparatus used.

In the first 13 sessions the participants performed seven exercises, one for each muscle group, with an intensity of approximately $60 \%$ of 1RM. The exercises were: Chest press, triceps extension, pulley exercises, dumbbell biceps curl, lateral raise, horizontal leg press and seated calf raise, with three sets for each exercise and 15 repetitions for the upper limbs as well as 20 repetitions for the lower limbs.

Intensity was increased in the 12 subsequent sessions, with approximately $70 \%$ of $1 \mathrm{RM}$. The training volume was increased while maintaining the previous exercises. Incline dumbbell press, untucked horizontal row, front raise, extension, flexion, seated adduction and abduction were added, totaling 14 exercises. Three sets were performed for each exercise, with 12 repetitions for upper limbs and 15 repetitions for lower limbs, except for calf and adductor and abductor muscles, totaling 20 repetitions. 
In the last 12 sessions, there was an increase in intensity with approximately $80 \%$ of $1 \mathrm{RM}$, and one more exercise was added for each smaller muscle group with a further exercise for the thighs and abdominal muscles, totaling 20. The previous exercises were maintained, and concentration curl, French curl, hack squat, standing calf raise, straight arm crunch and oblique crunch were added. A total of 10 exercises were performed on each training day. Three sets were performed for each exercise with 10 repetitions for the upper limbs and 12 repetitions for the lower limbs except for the calves, abs, adductors and abductors, which continued with 20 repetitions.

The interval between sets was one to two minutes while the interval between exercises was two to three minutes. The load increment was equal in all training stages. When the patient had performed the three sets with the repetitions stipulated in a given exercise, he or she would receive a weight increase in the exercise at the next session to maintain the intensity.

To compare functional capacity before and after weight training, we used the paired student's t-test and/or paired Wilcoxon test, with a statistical significance level of $a=0.05$.

\section{RESULTS}

Of the 23 participants, 18 (78.3\%) were women. The average age was 68.3 (6.7) years. Among the comorbidities, 19 (82.6\%) had a diagnosis of dyslipidemia and 13 (56.5\%) had been diagnosed with hypertension. There was a significant improvement in almost all functional assessment tests from $7.6 \%$ to $33.4 \%$. The mean walking time was $1.3 \mathrm{~m} / / \mathrm{s}$ in the pre-training period, and $1.4 \mathrm{~m} / \mathrm{s}$ after training.

Table 1 shows the functional capacity assessment of patients with T2DM before and after the weight training period. An improvement was seen in all the tests performed, except for the timed unipedal stance test (Table 1).

After the weight training period, there was a significant reduction in SBP both at rest and after exertion. In the tests of activities of daily living for physically active elderly people. There was also a reduction in DBP in all measurements, with a significant reduction at rest and after exertion in almost all the functional assessment and daily activity tests for physically active older people (Table 2).

Figure 1: shows the initial and final SBP and DBP behavior during the 37 weight training sessions. The initial SBP appears higher than the final reading in half of the weight training sessions. As for the DBP, the initial reading was higher than the final reading in most sessions.

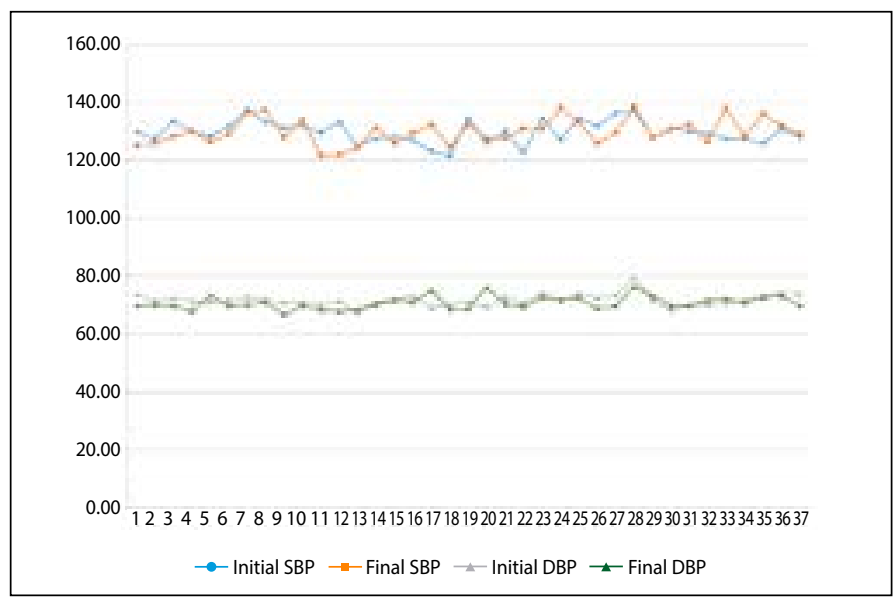

Figure 1. Mean initial and final systolic and diastolic blood pressure readings taken during the 37 weight training sessions.

Table 1. Tests to evaluate functional capacity, conducted before and after weight training and progressive loads, in elderly subjects with type 2 diabetes mellitus.

\begin{tabular}{|c|c|c|c|c|}
\hline & $\begin{array}{c}\text { Pre - Training } \\
\text { Mean (SD) } \\
\end{array}$ & $\begin{array}{c}\text { Post - Training } \\
\text { Mean (SD) }\end{array}$ & Difference \% & Evaluation \\
\hline \multicolumn{5}{|l|}{ Walking } \\
\hline 10 meters usual speed (seconds) & $11.1(2.0)$ & $9.7(1.8)^{*}$ & $13.0^{*}$ & Improved \\
\hline 10 meters maximum speed (seconds) & $7.7(1.7)$ & $6.9(1.3)^{*}$ & $10.6^{*}$ & Improved \\
\hline 800 meters (seconds) ${ }^{+}$ & $674.2(87.5)$ & $623.1(104.3)^{*}$ & $7.6^{*}$ & Improved \\
\hline \multicolumn{5}{|l|}{ Balance (seconds) } \\
\hline 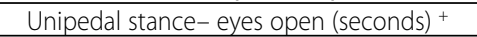 & $18.6(11.3)$ & $15.3(11.5)^{*}$ & $17.5^{*}$ & Decreased \\
\hline Unipedal stance - eyes closed (seconds) ${ }^{+}$ & $4.7(3.2)$ & $5.3(5.6)$ & 13.0 & \\
\hline Tandem stance (seconds) & $26.3(8.4)$ & $29.0(5.0)^{*}$ & $10.3^{*}$ & Improved \\
\hline Sitting and getting around (seconds) & $60.3(12.5)$ & $50.7(9.8)^{*}$ & $15.9^{*}$ & Improved \\
\hline Getting up from the ground (seconds) ${ }^{++}$ & $9.8(6.3)$ & $7.6(4.0)^{*}$ & $21.5^{*}$ & Improved \\
\hline Getting up from the chair 5 times (seconds) & $13.6(2.1)$ & $11.2(1.9)^{*}$ & $18.2^{*}$ & Improved \\
\hline Climbing ladder (seconds) & $18.0(9.5)$ & $12.0(6.8)^{*}$ & $33.4^{*}$ & Improved \\
\hline Manual skills (seconds) & $14.3(4.7)$ & $11.7(3.7)^{*}$ & $18.3^{*}$ & Improved \\
\hline Putting on socks (seconds) & $10.5(7.3)$ & $9.7(5.2)$ & 7.3 & - \\
\hline Climbing steps $(\mathrm{cm})$ & $64.1(11.7)$ & $67.8(8.0)^{*}$ & $5.1^{*}$ & Improved \\
\hline \multicolumn{5}{|l|}{ Maximum load test $(\mathrm{Kg})^{+++}$} \\
\hline Upper limbs & $12.0(4.8)$ & $14.5(5.1)^{*}$ & $20.8^{*}$ & Improved \\
\hline Lower limbs & $65.2(16.9)$ & $80.4(19.4)^{*}$ & $23.4^{*}$ & Improved \\
\hline
\end{tabular}

${ }^{+} \mathrm{n}=22$ participants, ${ }^{++} \mathrm{n}=20$ participants, ${ }^{+++}$BRZYCKI, 1993, ${ }^{*} \mathrm{p}<0.05$

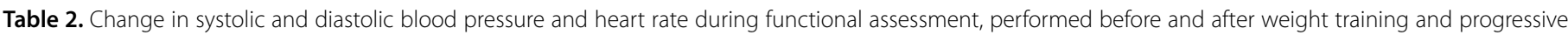
loads, in elderly patients with type 2 diabetes mellitus.

\begin{tabular}{|c|c|c|c|c|c|c|c|c|}
\hline & \multicolumn{4}{|c|}{ Pre-Training } & \multicolumn{4}{|c|}{ Post-Training } \\
\hline & SBP & DBP & $\mathrm{HR}_{1}$ & $\mathrm{HR}_{2}$ & SBP & DBP & $\mathrm{HR}_{1}$ & $\mathrm{HR}_{2}$ \\
\hline At rest & $136.0(16.0)$ & $75.9(10.58)$ & $84.3(16.1)$ & - & $129.0^{*}(14.0)$ & $71.7^{*}(10.5)$ & $82.2(16.6)$ & - \\
\hline \multicolumn{9}{|l|}{$10 \mathrm{~m}$ walk } \\
\hline Usual speed & - & - & $\begin{array}{c}89.9 \\
(18.7) \\
\end{array}$ & $92.4(19.5)$ & - & - & $86.0(14.9)$ & $90.1(17.6)$ \\
\hline Maximum speed & $141.6(19.9)$ & $75.9(12.5)$ & $85.7(19.0)$ & $95.4(18.5)$ & $131.3^{*}(14.59)$ & $\begin{array}{l}73.7 \\
(9.6) \\
\end{array}$ & $86.8(19.3)$ & $96.2(21.4)$ \\
\hline Sitting and getting around & $145.4(18.0)$ & $78.4(13.9)$ & $83.3(17.6)$ & $100.9(17.6)$ & $135.6^{*}(16.5)$ & $71.0^{*}(13.1)$ & $84.3(18.0)$ & $106.3(21.8)$ \\
\hline Getting up from the floor ${ }^{+}$ & $140.8(21.1)$ & $76.6(13.3)$ & $85.9(18.1)$ & $96.1(19.5)$ & $130.1^{*}(19.4)$ & $71.7^{*}(12.7)$ & $83.6(19.2)$ & $93.6(17.4)$ \\
\hline Getting up from the chair - 5 times & $138.6(22.1)$ & $74.6(12.1)$ & $84.4(17.6)$ & $96.1(18.5)$ & $131.1^{*}(17.5)$ & $\begin{array}{c}73.6 \\
(10.2) \\
\end{array}$ & $83.0(16.8)$ & $93.8(16.3)$ \\
\hline
\end{tabular}

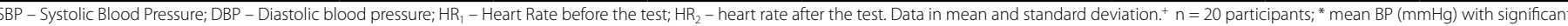
difference, for measurements performed during the physical tests, before and after 37 training sessions. 
Regarding the variations in SBP and DBP, it can be seen that the SBP presented a variation with an increase of more than $10 \mathrm{mmHg}$ in three of the 37 sessions. The DBP increased by more than $5 \mathrm{mmHg}$ in only two of the 37 sessions (Figure 2).

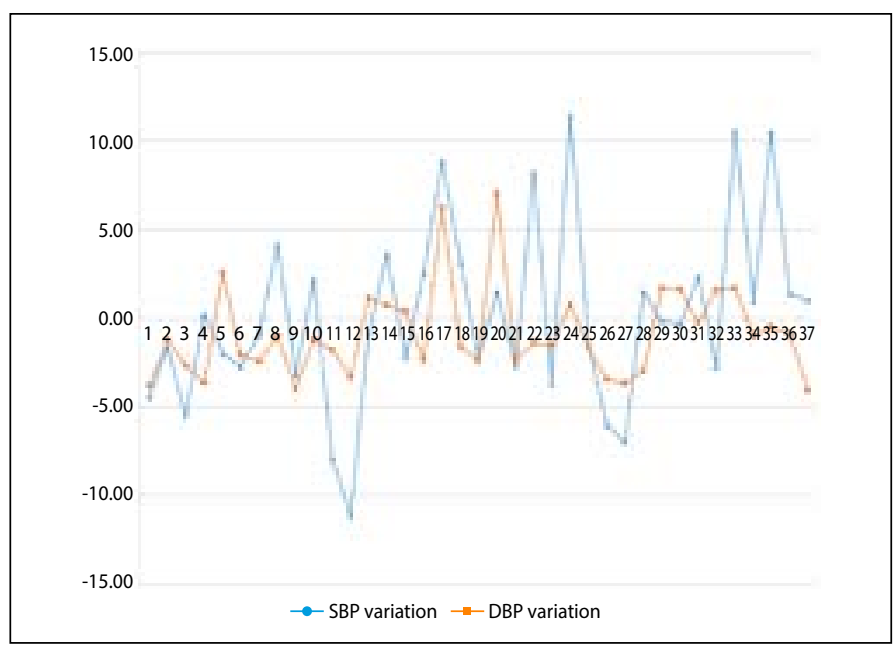

Figure 2. Mean variation in systolic and diastolic blood pressure during each session, measured during the 37 weight training sessions.

\section{DISCUSSION}

This study showed significant improvement in almost all functional assessment tests before and after the Training Program. In the 800-meter walking/running tests, sitting and getting around the house, climbing stairs, getting up from the ground and manual skills showed a statistically significant improvement, indicating an improvement in the patients' functional capacity.

There are few studies on strength training that have used tests proposed by Andreotti and Okuma. ${ }^{15}$ Therefore, other parameters were used to analyze the results found. Corroborating our results, a study showed an improvement in most tests for the entire sample. The 800-meter walk test showed an improvement, but it was not significant. ${ }^{18}$

A study that proposed a swimming program for elderly women showed an improvement in the $800 \mathrm{~m}$ walking tests, sitting and getting around the house, climbing steps, climbing ladders, getting up from the ground and putting on socks. ${ }^{19}$

Another localized training study, focusing on the main muscle groups and cardiorespiratory system, and designed for healthy older people, which also used the tests proposed by Andreotti and Okuma, ${ }^{15}$ showed that the initial tests were superior to our findings in almost all tests except the step test. However, at the end of the study physical progress was not significant in the test battery, except for the putting on socks test. ${ }^{20}$

The studies listed above ${ }^{18-20}$ started with better initial results than our findings, showing that the Resistance Training Program carried out in our study was superior for improving functional capacity.

Regarding the $5 x$ sit-to-stand test, in the pre-training test the results suggest a risk of falls. However, in the final test the values were very close to the cutoff values. Falls in the elderly are related to extrinsic and intrinsic factors, and programs such as the one proposed in this study may contribute to their prevention.

When analyzing maximal strength of the lower and upper limbs, we observed an improvement that may have contributed to the positive performance of most of the functional capacity tests. It is recognized that walking speed may be indicative of increased life expectancy in the elderly. ${ }^{21}$ Our findings show that the mean walking speed was considered exceptional, with $1.3 \mathrm{~m} / \mathrm{s}$ in the pre-training period and $1.4 \mathrm{~m} / \mathrm{s}$ after training, which may indicate benefits of resistance training in the promotion and maintenance of walking speed in elderly patients with T2DM.

Lower limb strength may interfere with walking speed, particularly at maximum speed, as well as other variables. ${ }^{22}$ Studies show that resistance training is able to increase the strength of elderly men with and without $\mathrm{T} 2 \mathrm{DM},{ }^{10,23}$ and that high intensity progressive interval resistance training increases strength without any change in the type of fibers in men with diabetic polyneuropathy. ${ }^{24}$

The results obtained from an analysis of the Tandem Stance balance test indicate an improvement in the body balance of the patients investigated, and a lower risk of falls. It is recognized that people with DM have a higher risk of falls than those without the disease. Accordingly, balance training combined with strength training reduces the risk of falls, improving proprioception and reaction time while increasing lower limb strength. ${ }^{8}$

Resistance training increases muscle strength. However, we cannot deduce that it prevents falls, since there is a stronger relation between falls and muscle power than with strength per se. What is known is that the best results are achieved with training that alternates high and low muscle contraction speeds., ${ }^{9,25}$

It is a recognized fact that resistance training is able to increase muscle strength in supervised training two months into the program. However, when supervision is suppressed, there is a tendency for strength to remain the same. ${ }^{5,11}$ Monitoring by a physical education professional can optimize results. Increased muscle strength may contribute to improved functional capacity and greater engagement in physical activity, reducing the risk of debility in the elderly. ${ }^{26}$

With regard to aerobic fitness, the greatest benefits are evidenced in elderly individuals who perform weight training in combination with aerobic training, when compared to exclusive aerobic training. Weight training can influence an active lifestyle, and individuals should be encouraged to engage in physical exercise programs, as it is recognized that older people tend to have a higher degree of sarcopenia. ${ }^{27}$

In analyzing BP values, we found a significant reduction both at rest and after exertion during the tests. BP reduction might be due to a reduction in the peripheral resistance of blood vessels and an increase in muscle strength, which reduces cardiac overload for activities with the same load.

Men with higher strength levels are less likely to develop hypertension compared to men with lower strength levels. This relationship is independent of cardiovascular fitness, although there is a moderate correlation between strength and cardiovascular fitness. ${ }^{28}$

Studies with hypertensive women also showed a reduction in SBP and DBP.7 The results obtained in the Weight Training Program were similar, with a reduction in SBP and DBP, yet without aerobic training. Studies show that the training period is important for BP reduction. ${ }^{5,6}$ In our study, the 12-week period was sufficient to lower the BP, possibly due to the higher training volume proposed.

Studies with adults show that resistance training is related to increased muscle mass and consequent improvement of the peripheral skeletal muscle pump, ${ }^{29}$ and that long-term weight training does not adversely affect BP, but is a protective factor for hypertensive patients. 7,28,29

During Hypertrophic Resistance Training, the BP levels of elderly patients with T2DM were satisfactory for moderate activities, since there was little variation between the start and end of the training sessions. There was a greater increase in SBP values in only three sessions, and in DBP in only two. In most sessions, SBP and DBP were lower at the end than at the beginning of the training sessions, showing a possible peripheral hypotensive effect as a result of weight training. 


\section{CONCLUSIONS}

It was concluded that there was significant improvement in most functional tests. In the maximum load test we observed a significant increase in strength in the upper and lower limbs. These results show the improvement of functional capacity in elderly individuals with T2DM, and that hypertrophic resistance training is a valuable tool for improving or maintaining daily activities. The effect on SBP and DBP reduction is comparable to the results of resting and active aerobic training.

All authors declare no potential conflict of interest related to this article

AUTHORS' CONTRIBUTIONS: Each author made significant individual contributions to this manuscript. JTG: data collection, writing of the article, data analysis, review of the manuscript; VC: data collection, data analysis, statistical analysis and review; MLZ: writing of the article, data analysis and review. All authors reviewed and approved the final version of the manuscript.

\section{REFERENCES}

1. Nelson ME, Rejeski WJ, Blair SN, Duncan PW, Judge JO, King AC, et al. Physical Activity and public health in older adults: recommendation from the American College of Sports Medicine and the American Heart Association. Med Sci Sports Exerc. 2007;39(8): 1435-45

2. Colberg SR, Sigal RJ, Fernhall B, Regensteiner JG, Blissmer BJ, Rubin RR, et al. Exercise and Type 2 Diabetes. The American College of Sports Medicine and the American Diabetes Association: joint position statement. Diabetes Care. 2010;33(12): e147-67.

3. American College of Sports and Medicine and American Diabetes Association. Exercise and Type 2 Diabetes: Joint Position Stand. Medicine \& Science in Sports e Exercise. Special Communication. 2010:2282-303.

4. Brooks N, Layne JE, Gordon PL, Roubenoff R, Nelson ME, Castaneda-Sceppa C. Strength training improves muscle quality and insulin sensitivity in Hispanic older adults with type 2 diabetes. Int J Med Sci. 2007;4(1):19-27

5. Dunstan DW, Vulikh E, Owen N, Jolley D, Shaw J, Zimmet P. Community center-based resistance training for the maintenance of glycemic control in adults with type 2 diabetes. Diabetes Care. 2006;29(12):2589-91.

6. Mavros Y, Kay S, Anderberg KA, Baker MK, Wang Y, Zhao R, et al. Changes in insulin resistance and HbA1C are related to exercise-mediated changes in body composition in older adults with type 2 diabetes: interim outcomes from the GRET2DO trial. Diabetes care. 2013;36(8):2372-9.

7. Rego AR, Gomes AL, Veras RP, Drummond Jr E, Alkimin R, Dantas EH. Pressão arterial após Programa de Exercício Físico Supervisionado em mulheres idosas hipertensas. Rev Bras Med Esporte. 2011;17(5):300-4.

8. Morrison S, Colberg SR, Mariano M, Parson HK, Vinik Al. Balance Training Reduces Falls Risk in Older Individuals With Type 2 Diabetes. Diabetes Care. 2010;33(4): 748-50.

9. Antero-Jacquemin JS, Santos P, Garcia PA, Dias RC, Dias JM. Comparação da função muscular isocinética dos membros inferiores entre idosos caidores e não caidores. Fisioter Pesq. 2012;19(1):39-44

10. Cauza E, Hanusch-Enserer U, Strasser B, Ludvik B, Metz-Schimmerl S, Pacini G, et al. The relative benefits of endurance and strength training on the metabolic factors and muscle function of people with type 2 diabetes mellitus. Arch Phys Med Rehabil. 2005;86(8):1527-33.

11. Dunstan DW, Daly RM, Owen N, Jolley D, Vulikh E, Shaw J, Zimmet P. Home-based resistance training is not sufficient to maintain improved glycemic control following supervised training in older individuals with type 2 diabetes. Diabetes Care. 2005;28(1):3-9.

12. Guralnik JM, SimonsickEM, Ferrucci L, Glynn RJ, Berkman LF, Blazer DG, et al. A short physical performance battery assessing lower extremity function: Association with self-reported disability and prediction of mortality and nursing home admission. J Gerontol. 1994;49(2):M85-94.

13. Rogers ME, Rogers NL, Takeshima N, Islam MM. Methods to assess and improve the physical parameters associated with fall risk in older adults. Prev Med. 2003;36(3): 255-64.

14. Shubert TE, Schrodt LAVS, Busby-Whitehead J, Giuliani CA. Are Scores on Balance Screening Tests Associated with Mobility in Older Adults? J Geriatr Phys Ther. 2006;29(1):35-9.
15. Andreotti RA, Okuma SS. Validação de uma bateria de testes de atividades da vida diária para idosos fisicamente independentes. Rev Paul Educ Fis. 1999;13(1):46-66.

16. Brown LE, Weir JP, Oliveira HB, Bottaro M, Lima LC, Fernandes Filho J. Recomendação de procedimentos da Sociedade Americana de Fisiologia do Exercício (ASEP) I: avaliação precisa da força e potência muscular. Rev Bras Cienc Mov. 2003;11(4): 95-110.

17. Nascimento MA, Cyrino ES, Nakamura FY, Romanzini M, Pianca HJ, Queiróga MR. Validação da equação de Brzycki para a estimativa de 1-RM no exercício supino em banco horizontal. Rev Bras Med Esporte. 2007;13(1):47-50

18. Passos BM, Souza LH, Silva FM, Lima RM, Oliveira RJ. Contribuições da hidroginástica nas atividades da vida diária e na flexibilidade de mulheres idosas. Rev Educ Física/UEM. 2008;19(1):71-6.

19. Rabelo RJ, Bottaro M, Oliveira RJ, Gomes L. Efeitos da natação na capacidade funcional de mulheres idosas. Rev Bras Cienc Mov. 2004;12(3):57-60.

20. Hernandez ES, Barros JF. Efeitos de um programa de atividades físicas e educacionais para idosos sobre o desempenho em testes de atividades diárias. Rev Bras Cienc Mov. 2004;12(2):43-50.

21. Studenski S, Perera S, Patel K, Rosano C, Faulkner K, Inzitari M, et al. Gait speed and survival in olde adults. JAMA. 2011;305(1):50-8.

22. Nomura T, Ikeda Y, Nakao S, Ito K, Ishida K, Suehiro T, et al. Muscle strenght is a marker insulin resistance in patients with type 2 diabetes: a pilot study. Endocr J. 2007; 54(5):791-6.

23. Ibañez J, Gorostiaga EM, Alonso AM, Forga L, Arguelles I, Larrión JL, et al. Lower muscle strength gains in older man with type 2 diabetes after resistance training. J Diabetes Complications. 2008;22(2):112-8.

24. Praet SF, Jonkers RA, Schep G, Stehouwer CD, Kuipers H, Keizer HA, et al. Long-standing, insulin-treated type 2 diabetes patients with complications respond well to short-term resistance and interval exercise training. Eur J Endocrinol. 2008;158(2):163-72.

25. Reid KF, Fielding RA. Skeletal muscle power: a critical determinant of physical functioning in older adults. Exerc Sport Sci Rev. 2012;40(1):4-12

26. Hovanec N, Sawant A, Overend TJ, Petrella RJ, Vandervoort AA. Resistance Training and Older Adults with Type 2 Diabetes Mellitus: Strength of the Evidence. J Aging Res. 2012;2012:284635.

27. Lubans DR, Plotnikoff RC, Jung M, Eves N, Sigal R. Testing mediator variables in a resistance training intervention for obese adults with type 2 diabetes. Psychol Health. 2012;27(12):1388-404.

28. Maslow AL, Sui X, Colabianchi N, Hussey J, Blair SN. Muscular Strength and Incident Hypertension in Normotensive and Prehypertensive Men. Med Sci Sports Exerc. 2010;42(2):288-95.

29. Cordina RL, O'Meagher S, Karmali A, Rae CL, Liess C, Kemp GJ, et al. Resistance training improves cardiac output, exercise capacity and tolerance to positive airway pressure in Fontan physiology. Inter J Cardiol. 2013;168(2):780-8 